\title{
GENERATION Y PERCEPTIONS AND EXPECTATIONS OF FOOD QUALITY LABELS IN THE CZECH REPUBLIC AND POLAND
}

\author{
Šárka Velčovská1, Dominika Hadro² \\ ${ }^{1}$ Department of Marketing and Business, Faculty of Economics, VŠB - Technical University of Ostrava, \\ 17. listopadu 15/2172, 70833 Ostrava-Poruba, Czech Republic \\ ${ }^{2}$ Department of Finance, Wroclaw University of Economics, ul. Komandorska 118-120, 53-345 Wrocław, Poland
}

\begin{abstract}
VELČOVSKÁ ŠÁRKA, DOMINIKA HADRO. 2018. Generation Y Perceptions and Expectations of Food Quality Labels in the Czech Republic and Poland. Acta Universitatis Agriculturae et Silviculturae Mendelianae Brunensis, 66(1): 0325-0334.

The paper advances the topic of food quality labels. The main goal of the study is to explore generation Y perceptions and expectations of food quality labels in the Czech Republic and Poland. The data were collected through an online survey from 372 respondents, involving 221 of Czechs and 151 of Poles. The statistical analysis procedures including descriptive statistics, Chi-square test and Mann-Whitney U test were performed to discover whether significant differences do exist between Czech and Polish consumer attitudes to the topic. Findings show that the number of food quality labels is perceived as strongly high and confusing, it is evident mainly in the Czech Republic. Impact of quality labels on food purchases is therefore limited and the labels benefits are not understood in full range. Statistically significant differences were confirmed between attitudes of Czechs and Poles to the food products characteristics that should be guaranteed by quality labels. Futher, Czech and Polish respondents differ in their opinion on the fee for the certification and credible administrator of the labels.
\end{abstract}

Keywords: Czech Republic, consumers, food quality, generation Y, Poland, quality labels

\section{INTRODUCTION}

In era of globalization, consumers are more caution in their food products purchases. They look for quality cues to help them infer product quality and reduce the risk of purchase decision. Consequently, a quality labels has become an important variable in food choice. They are primarily intended to work as a quality cue, reducing consumer uncertainty associated with food purchases, regarding expected product characteristics and the production process. Consumers can weigh quality labels against other characteristics during their decision making process. Findings by Bredahl and Poulsen (2002) confirm that products with quality labels are generally perceived to be of higher quality. Consumers pay more attention to quality labels also in such situation when the product is unbranded or the brand is not familiar (Iop et al., 2006). But it seems labels are performing these functions only to a certain extent.

The problem lies in an expansion of quality labels during last decades, with groups of manufacturers, retailers, regional and national authorities, the European Union (EU) institutions and others supporting them in various ways. However, many of them failed. Consumers often ignore quality labels due to a lack of knowledge and the labels have been misunderstood by consumers (Grunert, 2002). In addition, different consumer segments react to and use such labels in different ways. Some are interested only in organic production, some pay attention and attach positive utility to all labels, and some ignore the labels and are mostly interested in price regardless the product quality (Grunert, 2002).

In this context, it is necessary to explain the concept of food quality and its attributes. The term "food quality" is defined differently by 
consumers, producers, certification institutions or any other subjects based on subjective and objective assessment of the product. (United Nations, 2007). A detailed taxonomy of food quality attributes was done by Caswell (1997) who proposed following groups of attributes: food safety attributes, nutrition attributes, value attributes, package attributes and process attributes. This approach was later expanded and the quality attributes were divided into product characteristics, involving food safety, nutrition characteristics, sensory characteristics, functional characteristics and image, and process characteristics such as animal welfare or organic production (Grebitus, 2008).

Mentioned taxonomies do not take into account whether the characteristics are perceivable for consumers. Therefore, categorisation of quality characteristics based on the perceived quality should be applied. From this perspective, intrinsic quality ques (e.g. size, colour, appearance), extrinsic quality ques (e.g. price, brand name, labelling, nutrition information), experience quality attributes (e.g. taste, freshness) and credence quality attributes (e.g. healthfulness, naturalness, way of production) are distinguished (Oude Ophuis and Van Trijp, 1995). Only quality cues can be used to communicate food quality as they are the only characteristics to be perceived and evaluated by consumers before purchase (Grebitus, 2008).

It is also important to understand, how consumers themselves look at the food quality and its attributes. According to results of the research study conducted in selected European countries (Van Rijswijk and Frewer, 2008), food quality is perceived by consumers in terms of "taste", "good product" associated with a "proper production method, "natural/organic", "freshness" and "without risk". Nowadays, consumers expect their food to be safe, wholesome, tasty, and typical, i.e. linked to tradition and land (Lazzaroni et al., 2013). They are primarily interested in these quality indicators when choosing products because they feel they have no way of assessing the safety level of a product, or, alternatively, because they have confidence that the food safety is guaranteed. Therefore, consumers turn to food quality labels as a quality cue to form their expectations about the product quality and to help them make purchase decision.

Across Europe, several quality schemes co-exist with the aim of informing consumers and providing trust on food quality characteristics (Gracia and de-Magistris, 2016; Chalupová et al., 2016). Different ways in food quality and labelling policies of EU member states reflect differences in historical evolution, organisation and development of food industries, as well as different consumer interests, attitudes and behaviour (Verbeke, 2013). It is evident, that consumers are flooded with labels symbolizing quality of the food, as their number rose dramatically over past years due to the need to protect products and to differentiate the offerings respectively (Bonadonna et al., 2017; Jarossová and Pazúriková, 2014).

In the CR, consumers are provided with a substantial amount of food quality labels. At the national level, the Klasa label has a dominant position and can be actually underlined as the main quality programme in the CR (Chalupová et al., 2016). Apart from Klasa, Czech consumers can meet more than 40 other labels, covering the product quality, product origin, organic farming or other specific characteristics of a food products, e.g. the Czech Product - guaranteed by Federation of the Food and Drink Industries of the CR, Regional Food, Fair Food, Healthy Choice, Protected Geographical Indication (PGI), Protected Designation of Origin (PDO), Traditional Speciality Guaranteed (TSG), Organic Farming.

Similarly to the CR, a high number of quality labels is observed in Polish food products market. The best-known labels at the national and regional level are the Quality Tradition, Try Fine Food, Our Culinary Heritage - Tastes of Regions. Consumers can also find regional and local labels related to the individual provinces of PL. In addition, food products sold in PL carry a wide range of other quality labels, such as Healthy Choice, PGI, PDO, TSG, etc.

Given the plethora of quality guarantees that already exist, the question arises as to whether there is any sense to these initiatives. A series of studies have been done on the role of food quality schemes in the consumer decision-making process (e.g. Gracia and De-Magistris, 2016; Grunert, 2005; Grunert and Aachmann, 2016; Maehle et al., 2015; Szakály et al., 2016; Van Rijswijk and Frewer, 2008; Velčovská and Del Chiappa, 2015; Velčovská and Klapilová, 2016; Verbeke et al., 2012). As the results of these studies show, awareness of food quality labels is quite low and consumers do not even perceive the presence of the labels when shopping. It could be understand as a sign of the food labels inflation. With their rising number, it is impossible for the consumers to differentiate them (Chalupová et al., 2016). According to data of TNS Opinion \& Social network from 2012 within Special Eurobarometer survey (conducted in the 27 member states of the EU on the sample of 26593 respondents aged 15 years and over), two-thirds of EU citizens (67\% in the CR and only $48 \%$ in PL) check food purchases to see if they have quality labels that ensure specific characteristics, however only few do this consistently (15\% in the CR, $13 \%$ in PL) (European Commission, 2012). Survey of STEM/MARK agency from October 2015 conducted in the CR has revealed a low awareness of food quality labels among Czech consumers. When buying food, only $9 \%$ of Czechs definitely prefer products with quality labels. The Klasa label with $82 \%$ of spontaneous and $87 \%$ of aided awareness is the best-known label in the CR. Spontaneous awareness of other labels is less than $25 \%$. Information deficit is perceived as the main barrier 
in purchasing certified products (STEM/MARK, 2015). In PL, only $7 \%$ of consumers prefer products certified with quality labels when buying food. Any food quality label was spontaneously mentioned by Polish respondents, aided awareness is $63 \%$ for Quality Tradition, 81\% for Try Fine Food and $36 \%$ for Our Culinary Heritage - Tastes of Regions (Velčovská, 2017). Overall recognition of individual EU food quality logos is low, only $26 \%$ of Czechs and $13 \%$ of Poles are aware of the PDO, $25 \%$ of Czechs and $15 \%$ of Poles have recognized the PGI, and $29 \%$ of Czechs and $17 \%$ of Poles are aware of the TSG (European Commission, 2016).

Despite a high number of research studies dealing with consumer attitudes to food quality labels, the specifics of consumer generations and the differences among them are not taken into account. Also marketing strategy for food quality labels is usually formulated regardless the typical characteristics of these generations. The study elaborating the topic as it is perceived specifically by the generation Y consumers is missing, even though this generation is very important demographic segment of consumers in most developed societies (Rugimbana, 2007). Members of generation Y (so called Millenials or Echo boomers) were born during the '80s and the early '90s. Individual authors refer to different age boundaries of Generation Y, e.g. 1977 - 1994 (Sullivan and Heitmeyer, 2008), 1980 - 1994 (Bednall et al., 2012), or 1982 - 2000 (Brosdahl and Carpenter, 2011). What makes Millenials attractive to the companies is the size of this consumer segment and significant purchasing power they represent. In the EU member states, generation $\mathrm{Y}$ accounts for $24 \%$ of the adult population (Stokes, 2015). Lifestyle of Millenials is different from previous generations. They are sophisticated, technology wise, immune to most traditional marketing tools as they grew up with it all (WJSchroer, 2016). They prefer to communicate online rather than actual personal contact, also information sources used before making purchase can be more online than offline (Klapilová Krbová, 2016). They very often belong among innovators or early adopters according to the innovation adoption lifecycle theory (Mangold and Smith, 2012). A lower brand loyalty and diverse responses to brands are typical for them. Some studies have observed their willingness to pay more for brands that represent quality (Quintal et al., 2016).

With respect to importance of this generation, the main goal of the study is to explore generation $Y$ perceptions and expectations of food quality labels. The research was conducted in two closed EU countries, the Czech Republic (CR) and Poland (PL), with the purpose to compare consumer attitudes.

\section{MATERIALS AND METHODS}

The quality schemes aim to give consumers information on product quality, place or method of production, and help them to recognize higher-quality food products. However, this role of quality labels can be fulfilled only if consumers are aware of the existence and meaning of them. Although today's consumers give more attention to the food products quality, the current trend in food products certification has led to considerably grown number of quality labels both in an national and EU level and to the situation that instead of easier orientation in food quality, the effect is rather opposite. A large number of food quality labels cause consumer confusion (Horáček, 2014).

Therefore, in accordance with the main goal of the study, four partial study objectives were formulated: (1) to analyse the role of food quality labels in consumer purchase decision, (2) to examine the perception of quality labels benefits, (3) to identify expected characteristics of food quality labels, and (4) to investigate the perception of number of food quality labels on the market. With respect to the gap in literature, the study is focused on generation $\mathrm{Y}$ as the sizeable and lucrative consumer segment attractive to the companies.

Two questionnaires, one for Czech and the second for Polish consumers, were developed, differing only in language. The questionnaire was structured in accordance with mentioned partial study objectives. Five-item verbal rating scale to examine the role of food quality labels in purchase decision, seven-point Likert scale of agreement to measure perception of quality labels benefits, multiple choice questions to identify expected characteristics of food quality labels and perception of the number

I: Structure of respondents (\%)

\begin{tabular}{|c|c|c|c|}
\hline Gender & Male & 24.0 & 21.2 \\
\hline GeIIUCI & Female & 76.0 & 78.8 \\
\hline \multirow[b]{2}{*}{ Responsibility for food purchases } & Full & 46.2 & 58.3 \\
\hline & Partial & 33.9 & 35.1 \\
\hline \multirow[t]{2}{*}{ Education } & Secondary school & 52.1 & 50.5 \\
\hline & Higher school and university degree & 45.2 & 48.2 \\
\hline
\end{tabular}

Source: Own processing based on data from IBM SPSS Statistics 23.0. 
of food quality labels on the market were used in the questionnaire. Data were collected in March and April 2016 from generation Y individuals born between 1980 and 1995 and living in the CR and PL. The sample of respondents was conducted by judgemental sampling with respect to the role of women and men in household food purchases. According to study of Data Collect Agency from 2015, women dominate household food shopping (Ekonomický deník, 2016). This is also confirmed by the KPMG study from February 2016. Food products for family are regularly purchased by $75 \%$ of women and only $25 \%$ of men (Gastro \& Hotel, 2017). The same gender structure was respected in the study in each country. A total of 372 respondents, involving 221 of Czechs and 151 of Poles, completed the questionnaire. Final structure of respondents by gender and responsibility for food purchases is presented in Tab. I.

Data were analysed using IBM SPSS Statistics 23.0 and Microsoft Excel software. First, descriptive statistics such as simple frequencies and mean values were computed. In the next step, the results were analysed on the basis of socioeconomic characteristics of the respondents, involving country, gender, education and responsibility for food purchases. Chi-square test at 0.05 significance level was undertaken to test the dependences between nominal variables (Kozel et al., 2017). For values measured on ordinary scale, Mann-Whitney $\mathrm{U}$ test, as an alternative non-parametric statistical technique (when the data are not normally distributed) to a t-test was calculated to compare whether the medians of two data sets are equal (Milenović, 2011). Cramer's V coefficient (for nominal variables when the number of rows and columns or both is greater than two), Phi coefficient (for $2 \times 2$ contingency table with nominal variables) and Eta coefficient (to determine the degree of association between interval and nominal variables) were counted to prove the strength of relationship between variables, using these descriptors to interpret the coefficients: 0.00 and under 0.10 - negligible association, 0.10 and under 0.20 - weak association, 0.20 and under 0.40 - moderate association, 0.40 and under 0.60 - relatively strong association, 0.60 and under
0.80 - strong association, 0.80 and under 1.00 - very strong association (Rea and Parker, 2014).

It is necessary to specify the limitations of the research. The study was conducted in two EU countries and the results are related to the generation Y only. With regard to limited length of the paper, there is also limited scope of problem areas that could be presented.

\section{RESULTS AND DISCUSSION}

Results are structured into following sections: (1) Role of food quality labels in consumer purchase decision, (2) perception of food quality labels benefits, (3) identification of expected characteristics of quality labels, and (4) perception of number of quality labels on the market.

\section{Role of Food Quality Labels in Consumer Purchase Decision}

Respondents were asked whether they check the quality labels on product packaging when buying food. The labels are searched mostly or always by $38.9 \%$ of Czechs and $25.8 \%$ of Poles of generation Y. On the other hand, $13.1 \%$ of Czechs and $15.9 \%$ of Poles do not pay attention to them. Taking into focus gender of respondents and responsibility for food purchases, it can be observed that woman are more interested in food quality labels than men as well as respondents with full or partial responsibility for food purchases pay a higher attention to quality labels than respondents with low responsibility (Tab. II). According to data of TNS Opinion \& Social network from 2012 within Special Eurobarometer survey, 15\% of Czechs and $13 \%$ of Poles check consistently food purchases to see if they have quality labels (European Commission, 2012). The results of our research (Tab. II) are more positive.

Statistically significant difference do exist only between attention given to food quality labels by Polish men and women, $\chi^{2}(4, N=151)=14.713$, Sig. $=0.005, \mathrm{p}<0.05$, Cramer's $\mathrm{V}=0.312$ indicates a moderate association. Other relations between variables were not confirmed, respondents' country, education, responsibility for food purchases and gender of Czech respondents have no influence.

II: Attention given to food quality labels by gender, responsibility for food purchases and country of respondents (\%)

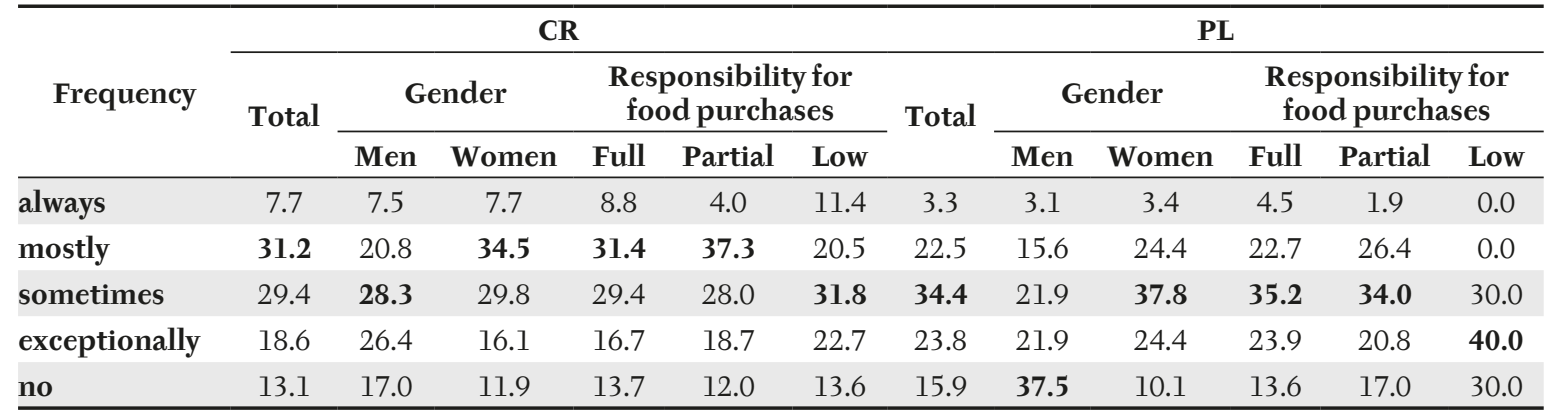

Source: Own processing based on data from IBM SPSS Statistics 23.0. 


\section{Perception of Quality Labels Benefits}

Respondents should evaluate the statements about food quality labels, using a 7-point scale of agreement ( $\mathrm{l}=\mathrm{I}$ absolutely disagree, 7 = I absolutely agree). The differences between Czech and Polish consumer attitudes were analysed. Based on the results of Shapiro-Wilk test of normality, we can conclude with $95 \%$ confidence that that the data tested are not normally distributed (p-value $<0.05$ ). Therefore, nonparametric Mann-Whitney U test as an alternative test to the independent sample t-test was undertaken to compare whether two population medians are equal or not. For this purpose, the following hypotheses were determined. HO: The distribution of answers is the same across categories of country, Hl: The distribution of answers is not the same across categories of country. The results of Mann-Whitney U test can be seen in Tab. III.

The third column in Tab. III contains Means counted from 7-point evaluation scale. A higher Mean indicate a higher level of agreement with the statement. Generally, the evaluations of all the statements are similar with Means from 2.86 to 4.19 , i.e. average or slightly below average rating. Poles agree a little less than Czechs with both, positively as well as negatively formulated statements. Respondents show the highest level of agreement with the statement "Quality labels facilitate food choice.".

The penultimate column of Tab. III gives the results of Mann-Whitney U test. Hypothesis HO is rejected for the statements "Quality labels make food products more expensive." ( $\mathrm{U}=12146.500$, Sig. $=0.000, \eta=0.221$ ), "I believe to food quality labels." (U = 13557.000, Sig. $=0.002, \eta=0.165)$ and "I am willing to pay more for food products with certified quality." $\quad(U=13175.000, \quad$ Sig. $=0.000$, $\eta=0.185)$. Czech respondents more agree with these statements than Poles, however Eta coefficients $\eta$ (the last column of Tab. III) indicate a weak associations between variables. For all other statements we retain the null hypothesis, i.e. the distribution of answers is the same across categories of country.

\section{Identification of Expected Characteristics of Food Quality Labels}

A various food product characteristics may be covered by food quality labels, involving product composition, healthy aspects, place or method of production, etc. It is essential to certify those product characteristics that are in the centre of consumer interest. Respondents were therefore asked to choose up to four food product characteristics significant for them that should be guaranteed by quality labels. The results are presented in Tab. IV.

These results can be compared with the findings of previous research studies. Lazzaroni et al. (2013) have found that consumers expect their food to be safe, wholesome and linked to tradition and land. This is corresponding with attitudes of Czech and Polish respondents. As an expected characteristic of a food that should be guaranteed by quality labels (Tab. IV), $66.4 \%$ of Czechs and $51.3 \%$ of Poles have mentioned a product without risk (i.e. safe), $20.9 \%$ of Czechs and $8.0 \%$ of Poles expect a food product beneficial to health, $31.8 \%$ of Czechs and $22.7 \%$ of Poles have chosen a nutritionally balanced product (i.e. wholesome). A long-term proven traditional way of production is important for $13.2 \%$ of Czechs and $22.0 \%$ of Poles, from $5.0 \%$ to $15.3 \%$ of Czech and Polish respondents have chosen the origin of the food in a domestic country, from local farms of local producers and/or in a particular region (i.e.

III: Perception of quality labels benefits by respondents' countrya

\begin{tabular}{|c|c|c|c|c|c|c|c|c|}
\hline Statement & Country & Mean & $\begin{array}{l}\text { Mean } \\
\text { Rank }\end{array}$ & $\begin{array}{c}\text { Mann- } \\
\text { Whitney U }\end{array}$ & $\begin{array}{l}\text { Wilcoxon } \\
\text { W }\end{array}$ & $\mathbf{Z}$ & $\begin{array}{l}\text { Asymp. } \\
\text { Sig. } \\
\text { (2-tailed })^{*}\end{array}$ & $\begin{array}{c}\text { Eta } \\
\text { coefficient }\end{array}$ \\
\hline \multirow{2}{*}{$\begin{array}{l}\text { Quality labels facilitate food } \\
\text { choice. }\end{array}$} & $\mathrm{CR}$ & 4.19 & 194.94 & \multirow{2}{*}{14820.500} & \multirow{2}{*}{26296.500} & \multirow{2}{*}{-1.863} & \multirow{2}{*}{0.062} & \multirow{2}{*}{ - } \\
\hline & PL & 3.86 & 174.15 & & & & & \\
\hline \multirow{2}{*}{$\begin{array}{l}\text { Quality labels make food } \\
\text { products more expensive. }\end{array}$} & $\mathrm{CR}$ & 3.63 & 207.04 & \multirow{2}{*}{12146.500} & \multirow{2}{*}{23622.500} & \multirow{2}{*}{-4.523} & \multirow{2}{*}{0.000} & \multirow{2}{*}{0.221} \\
\hline & PL & 2.86 & 156.44 & & & & & \\
\hline \multirow{2}{*}{$\begin{array}{l}\text { Quality labels guarantee } \\
\text { the quality of a food product. }\end{array}$} & $\mathrm{CR}$ & 3.96 & 190.76 & \multirow{2}{*}{15743.000} & \multirow{2}{*}{27219.000} & \multirow{2}{*}{-0.942} & \multirow{2}{*}{0.346} & \multirow{2}{*}{-} \\
\hline & PL & 3.82 & 180.26 & & & & & \\
\hline \multirow{2}{*}{$\begin{array}{l}\text { Certified products are higher } \\
\text { quality than those uncertified. }\end{array}$} & CR & 3.79 & 188.53 & \multirow{2}{*}{16237.500} & \multirow{2}{*}{27713.500} & \multirow{2}{*}{-0.448} & \multirow{2}{*}{0.654} & \multirow{2}{*}{-} \\
\hline & PL & 3.77 & 183.53 & & & & & \\
\hline \multirow{2}{*}{ I believe to food quality labels. } & $\mathrm{CR}$ & 4.08 & 200.66 & \multirow{2}{*}{13557.000} & \multirow{2}{*}{25033.000} & \multirow{2}{*}{-3.121} & \multirow{2}{*}{0.002} & \multirow{2}{*}{0.165} \\
\hline & PL & 3.54 & 165.78 & & & & & \\
\hline \multirow{2}{*}{$\begin{array}{l}\text { I usually prefer to buy foods } \\
\text { with quality labels. }\end{array}$} & CR & 3.48 & 190.80 & \multirow{2}{*}{15735.000} & \multirow{2}{*}{27211.000} & \multirow{2}{*}{-0.947} & \multirow{2}{*}{0.343} & \multirow{2}{*}{-} \\
\hline & PL & 3.32 & 180.21 & & & & & \\
\hline \multirow{2}{*}{$\begin{array}{l}\text { I am willing to pay more for } \\
\text { foods with certified quality. }\end{array}$} & $\mathrm{CR}$ & 3.78 & 202.38 & & 24651.000 & -3.494 & 0.000 & 0.185 \\
\hline & PL & 3.11 & 163.25 & & & & & \\
\hline
\end{tabular}

Source: Own processing based on data from IBM SPSS Statistics 23.0.

${ }^{a}$ Mann-Whitney U test, Grouping Variable: Country 
IV: Expected characteristics of food product guaranteed by quality labels (\%)

\begin{tabular}{lcc}
\hline \multicolumn{1}{c}{ Characteristics } & CR & PL \\
\hline composition of a product from a high-quality raw materials & $\mathbf{9 2 . 3}$ & $\mathbf{7 2 . 0}$ \\
\hline freshness & $\mathbf{5 4 . 1}$ & $\mathbf{7 1 . 3}$ \\
\hline $\begin{array}{l}\text { product without risk, a health-conscious product } \\
\text { the composition from natural ingredients, without added preservatives }\end{array}$ & $\mathbf{6 6 . 4}$ & $\mathbf{5 1 . 3}$ \\
\hline nutritionally balanced product & 46,8 & 45.3 \\
guarantee of quality assessment by an independent laboratory/institution & 31.8 & 22.7 \\
long-term proven traditional way of production & 15.0 & 27.3 \\
\hline food product that is beneficial to health & 13.2 & 22.0 \\
the origin of the food in a domestic country & 20.9 & 8.0 \\
\hline origin of food from local farms or from local producers & 11.8 & 15.3 \\
\hline positive references from consumers & 13.2 & 8.7 \\
the origin of the food in a particular region & 7.7 & 13.3 \\
\hline
\end{tabular}

Source: Own processing based on data from IBM SPSS Statistics 23.0.

products linked to tradition and land). In addition to these characteristics, according to findings of Van Rijswijk and Frewer (2008), food quality is perceived in terms of "good product" associated with a proper production method, "natural/ organic" and "freshness". As it is shown in Tab. IV, the composition of a product from a high-quality raw materials (i.e. "good product" associated with a proper production method) is the most important characteristic for Czech (92.3\%) and Poles respondents $(72.0 \%)$, the composition from natural ingredients and without added preservatives (i.e. "natural/organic") is expected by $46.8 \%$ of Czechs and $45.3 \%$ of Poles, and $54.1 \%$ of Czechs and $71.3 \%$ of Poles emphasizes a freshness of a product.

To summarize these results, Czechs and Poles of generation $\mathrm{Y}$ put emphasis mainly on the composition of a product from a high-quality raw materials. Poles attach a strong importance also to a freshness of a product, whereas a health-conscious product is the second most important factor for Czech respondents. Taking into account above mentioned theoretical approaches to food quality attributes and their taxonomies (Oude Ophuis and Van Trijp, 1995; Grebitus, 2008), so-called experience quality attributes (freshness) and credence quality attributes (healthfulness, naturalness, wholesomeness, way of production) are the characteristics expected by consumers to be guaranteed by food quality labels, i.e. those characteristics that cannot be perceived before purchase. A quality labels, together with nutritional information, production information and country-of-origin information, are therefore important to be used as an extrinsic quality cues to communicate mentioned food quality attributes as they are the only characteristics perceived and evaluated by the consumers before purchase.

Chi-squre test has confirmed relation between expected characteristics of food products and country of respondents, $\chi^{2}(12, \mathrm{~N}=372)=81.443$, Sig. $=0.000, p<0.05$. Gender and education of Czech or Polish respondents has no influence on perception of quality labels characteristics.

In order to fulfil their role and work as a quality cue, reducing consumer uncertainty associated with food purchases and motivating consumers to purchases of certified products, the quality labels must be credible. Respondents expressed their opinion on quality labels credibility in the context of the fee for the certification. Poles are more inclined to award the labels without the fee for the certification process, whereas attitudes of Czechs are ambiguous (Tab. V). The statistically significant difference between attitudes of Czech and Polish respondents to the fee for the certification process was confirmed, $\chi^{2}(1, N=372)=5.449$, Sig. $=0.020$, $\mathrm{p}<0.05$. Phi coefficient 0.121 indicates a weak relation between variables.

Further, respondents should indicate who is a trusted administrator of the quality labels for them. They could choose two options from the list of possible administrators. For Czech respondents, trusted labels would be those administered by the Federation of the Food and Drink Industries, Polish respondents consider an independent organizations (such as an interest groups or a consumer organizations) as the most trustworthy. Ministry of Agriculture is perceived as a credible administrator of the labels only by

V: Credibility of labels according to the fee for the certification (\%)

\begin{tabular}{lcc}
\multicolumn{1}{c}{ Credible labels } & CR & PL \\
\hline with fee for the certification & 48.0 & 35.8 \\
without fee for the certification & $\mathbf{5 2 . 0}$ & $\mathbf{6 4 . 2}$ \\
\hline
\end{tabular}

Source: Own processing based on data from IBM SPSS Statistics 23.0. 


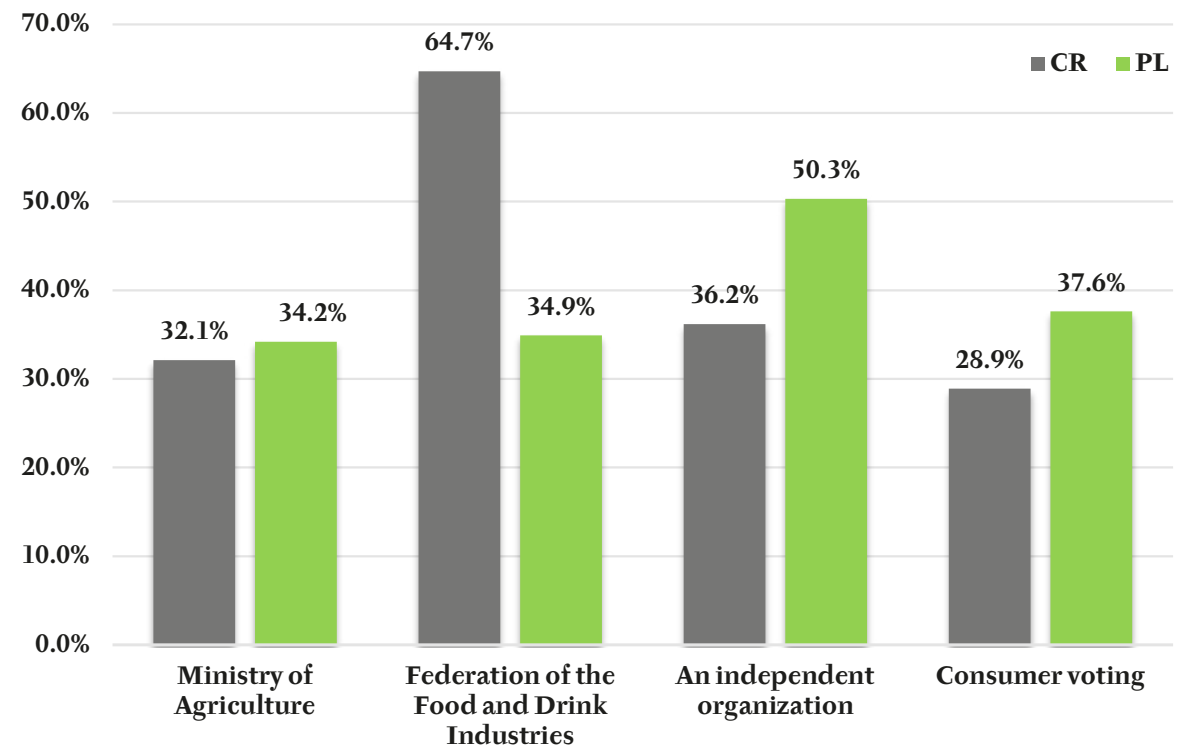

1: Trusted administrator of the labels by country

Source: Own processing based on data from IBM SPSS Statistics 23.0.

one third of Czechs and Poles (Fig. 1). Chi-square test confirmed the dependence between trusted administrator of labels and respondents' country, $\chi^{2}(4, \mathrm{~N}=372)=41.929$, Sig. $=0.000, \mathrm{p}<0.05$.

\section{Perception of the Number of Food Quality Labels on the Market}

The number of food quality labels is strongly high both in the Czech Republic as well as in Poland. Therefore, respondents were asked to express their opinion on the number and clarity of quality labels on the food products market. About forty percent of Czechs (40.7\%) and thirty percent (29.1\%) of Poles consider the number of food quality labels as too high and confusing. A quarter of respondents from both countries think that the number of quality labels is just right. About $9 \%$ of Czechs and $17 \%$ of Poles perceive it as low (Tab. VI).

Results of Chi-square test confirmed the statistically significant relation between perception of the number of food quality labels and respondents' country, $\chi^{2}(5, N=372)=16.124$, Sig. $=0.006, \mathrm{p}<0.05$, Cramer's $\mathrm{V}=0.208$ indicates a moderate association. There is also relation between perception of the number of labels and attention given to the quality labels during food purchases by Czech respondents, $\chi^{2}(12$, $\mathrm{N}=221)=30.105$, Sig. $=0.003, \mathrm{p}<0.05$, Cramer's $\mathrm{V}=0.213$, as well as by Polish respondents, $\chi^{2}(12$, $\mathrm{N}=151)=66.854$, Sig. $=0.000, \mathrm{p}<0.05$, Cramer's $\mathrm{V}=0.384$. According to Cramer's V values, there are moderate associations between variables. Czechs with regular attention given to food quality labels during their food purchases consider more often the number of food quality labels as high and confusing, whereas respondents with exceptional or no attention to the labels were mostly unable to assess the number of labels on the market. A considerable number of Poles (80\%) giving regular attention to food quality labels answered that the number of quality labels is just right. Those with exceptional or no attention paid to quality labels were not able to judge the number of quality labels on the market. In both countries, there is no relation between perception of the number of food quality labels and respondents' responsibility for food purchases or education.

When asking respondents about missing quality labels on the food products market, the label with guarantee of a health-conscious products, the certification of the products without

VI: The number of quality labels (\%)

\begin{tabular}{lcc}
\hline \multicolumn{1}{c}{ Number of quality labels } & CR & PL \\
\hline high and confusing & 40.7 & 29.1 \\
high, but clear & 9.0 & 3.3 \\
just right & 24.4 & 24.5 \\
low, but confusing & 7.7 & 14.6 \\
low and clear & 1.4 & 2.0 \\
I cannot judge, I do not care about the food quality labels & 16.7 & 26.5 \\
\hline
\end{tabular}

Source: Own processing based on data from IBM SPSS Statistics 23.0. 
palm oil and without added preservatives were mentioned by Czechs. Poles would most appreciate the certification of natural products, healthy products, fresh products or products without GMO, artificial additives and added preservatives. Among others, these characteristics were also mentioned in connection with the term „food quality" by respondents in the research of Van Rijswijk and Frewer (2008). This is supported also by Lazzaroni et al. (2013), consumers expect their food to be safe and wholesome.

\section{CONCLUSION}

There is no doubt that quality labels can have a considerable potential in improving consumer quality transparency. However, the findings of the research study are not very positive. The number of food quality labels is perceived as strongly high and confusing for consumers, it is particularly evident in the Czech Republic. It could be reason why respondents pay only limited attention to the quality labels when buying food and why they do not perceive the labels benefits in full range. Impact of quality labels on food products purchases is therefore limited. When comparing attitudes of Czechs and Poles, the differences are quite small.

The strategy of food quality labels should be reconsidered in both countries. Number of the labels need to be reduced in order to facilitate orientation in food quality and eliminate the misleading of consumers. Only few principal labels with clear focus and benefits are recommended to be present on the market. In order to fulfil their role to work as a quality cue for consumers in store, the quality labels should be a guarantee of those product characteristics that are in the centre of consumer interest. Czechs and Poles place emphasis mainly on composition of a product from a high-quality raw materials, a freshness of a product (the second most important factor for Poles and the third for Czechs), a health-conscious product (the second most important factor for Czechs and the third for Poles) and the composition from natural ingredients, without added preservatives. The perception of quality labels credibility is affected by the label administrator and by the certification process including the fee for certification. Czech and Polish respondents differ in their opinion on these factors. For Czech respondents, the most trusted labels would be those administered by the Federation of the Food and Drink Industries, attitudes of Czechs to the fee for the certification are ambiguous. Poles consider independent organizations to be the most trustworthy administrator of the labels (e.g. interest groups or consumer organizations) and they are more inclined to award the labels without the fee for the certification process.

In order to build more positive consumers' attitudes to the labels and to make competitive advantage of producers, the labels need to be supported and their promotion should be implemented into producers' marketing strategy. Producers should make a greater effort to let consumers know that their products are manufactured in order to achieve the highest quality standards. As a result, consumers could improve their knowledge and their trust in the product quality. It is obviously necessary to provide consumers relevant, transparent, complete and accurate information of the food quality and the quality labels in an understandable and consumer friendly way. Product attributes associated with food quality should be highlighted in promotion campaigns to attract consumers' attention and increase their interest in certified products. It is also necessary to take into account a suitable media for promotion of the labels with respect to generation Y specifics and their preference of online communication.

Generation Y consumers are inevitably connected to the internet, mobile phones and social media. They use them to find different product information and to make purchasing decisions. To develop of a mobile application and a websites could be solution that will give food producers a unique tool to easily communicate their food products quality to the generation Y consumers. The consumers could trace the food products and their quality characteristics, e.g. with an activity as simple as scanning QR code of the product. New media and modern technologies are therefore necessary communication channels for this consumer cohort.

In future research, it would be useful to conduct more extensive research with focus on other EU countries or to involve the generation $X$ and the generation Baby Boomers consumers into the comparison. It could be also interesting to perform factor and cluster analysis to create a consumer typology based on consumer attitudes to food quality and quality labels.

\section{Acknowledgments}

This paper is supported within Operational Programme Education for Competitiveness - Project No. CZ.1.07/2.3.00/20.0296 and within the project SP2016/106 An Intergenerational Comparison of Consumer Behaviour in the International Context. 


\section{REFERENCES}

BEDNALL, D. H., VALOS, M., ADAM, S. et al. 2012. Getting generation Y to attend: Friends, interactivity and half-time entertainment. Sport Management Review, 15(1): 80-90.

BONADONNA, A., MACAR, L., PEIRA, G. et al. 2017. The dark side of the European quality schemes: The ambiguous life of the Traditional Specialities Guaranteed. Quality - Access to Success, 18(156): 102-108.

BREDAHL, L. and POULSEN, C. S. 2002. Perceptions of pork and modern pig breeding among Danish consumers. Project paper No. 01/02. Aarhus: The Aarhus School of Business. Available at: https://pure.au.dk/ws/ files/32302745/pp0102.pdf [Accessed: 2017, June 12].

BROSDAHL, D. J. C. and CARPENTER, J. M. 2011. Shopping orientations of US males: A generational cohort comparison. Journal of Retailing and Consumer Services, 18(6): 548-554.

CASWELL, J. A. 1997. Uses of food labelling regulations. Paris: OECD. [Online]. Available at: https://www.iatp. org/files/Uses_of_Food_Labelling_Regulations.htm [Accessed: 2017, May 28].

CHALUPOVÁ, M., PROKOP, M. and ROJÍK, S. 2016. Regional food preference and awareness of regional labels in Vysočina region (Czech Republic). European Countryside, 8(2): 109-122.

EKONOMICKÝ DENÍK. C2016. Survey: Food shopping in households are changing [in Czech: Průzkum: Nákupy potravin v domácnostech se mění]. Ekonomický deník. [Online]. Available at: http:// ekonomicky-denik.cz/pruzkum-nakupy-potravin-v-domacnostech-se-meni/[Accessed: 2017, May 20].

EUROPEAN COMMISSION. 2012. Special Eurobarometer 389: Europeans' attitudes towards food security, food quality and the countryside. [Online]. Available at: http://ec.europa.eu/public_opinion/archives/ebs/ebs_389_ en.pdf [Accessed: 2017, May 20].

EUROPEAN COMMISSION. 2016. Special Eurobarometer 440: Europeans, agriculture and the CAP. [Online]. Available at: http://ec.europa.eu/COMMFrontOffice/PublicOpinion/index.cfm/Survey/getSurveyDetail/ instruments/SPECIAL/surveyKy/2087 [Accessed: 2017, May 20].

GASTRO \& HOTEL. (C2017. Shopping habits 2016: Two third of people purchase more than they have planned [in Czech: Nákupy zvyklosti 2016: Dvě třetiny lidí nakoupí více, než plánovaly]. GASTRO ఠ HOTEL profi revue. [Online]. Available at: http://gastroahotel.cz/rubriky/novinky-z-gastronomie/nakupnizvyklosti-2016-dve-tretiny-lidi-nakoupi-vice-nez-planovaly/_[Accessed: 2017, May 20].

GRACIA, A. and DE-MAGISTRIS, T. 2016. Consumer preferences for food labeling: What ranks first? Food Control, 61(3): 39-46.

GREBITUS, C. 2008. Food quality from the consumer's perspective: An empirical analysis of perceived pork quality. $1^{\text {st }}$ edition. Gottingen: Cuvillier Verlag.

GRUNERT, K. G. 2002. Current issues in the understanding of consumer food choice. Trends in Food Science $\sigma^{\circ}$ Technology, 13(8): 275-285.

GRUNERT, K. G. 2005. Food quality and safety: consumer perception and demand. European Review of Agricultural Economics, 32(3): 369-391.

GRUNERT, K. G. and AACHMANN, K. 2016. Consumer reactions to the use of EU quality labels on food products: A review of the literature. Food Control, 59(1): 178-187.

HORÁČEK, F. 2014. Chaos for hundreds of millions. There is too much quality labels on the Czech market [in Czech: Chaos za stovky milionů. Značek kvality je na českém trhu př́liš̌]. iDNES.cz. [Online]. Available at: http://ekonomika.idnes.cz/chaos-v-ceskych-znackach-kvality-do4-/ekonomika.aspx?c=A 140120_133534_ekonomika_fih [Accessed: 2017, May 12].

IOP, S. C. F., TEIXEIRA, E. and DELIZA, R. 2006. Consumer research: extrinsic variables in food studies. British Food Journal, 108(11): 894-903.

JAROSSOVÁ, M. A. and PAZÚRIKOVÁ, V. 2014. Traditional and regional foods from the Slovak consumer's view. In: The Proceedings of the 5th International Scientific Conference on Trade, International Business and Tourism: Application of Knowledge in Process of Business Dynamization in Central Europe. Manor House Mojmírovce, 16-17 October. Bratislava: EKONÓM, pp. 197-206.

KLAPILOVÁ KRBOVÁ, P. 2016. Shopping behaviour of generation Y: A comparison of Czech Republic and Slovakia. Acta Universitatis Agriculturae et Silviculturae Mendelianae Brunensis, 64(2): 617-626.

KOZEL, R., HAWRYSZ, L., VILAMOVÁ, Š. et al. 2017. Mystery e-mail/website customer service. A case study of retail companies. Scientific Papers of the University of Pardubice, Series D, 24(40): 95-107.

LAZZARONI, C., IACURTO, M., VINCENTI, F. et al. 2013. Consumer attitudes to food quality products of animal origin in Italy. In: KLOPČIČ, M., KUIPERS, A. and HOCQUETTE, J. F. (Eds.). Consumer attitudes to food quality products. EAAP publication No. 133. $1^{\text {st }}$ edition. Wageningen: Wageningen Academic Publishers, pp. 83-96.

MAEHLE, N., IVERSEN, N., HEM, L. et al. 2015. Exploring consumer preferences for hedonic and utilitarian food attributes. British Food Journal, 117(12): 3039-3063.

MANGOLD, W. G. and SMITH, K. T. 2012. Selling to Millennials with online reviews. Business Horizons, 55(2): 141-153.

MILENOVIĆ, Ž. 2011. Application of Mann-Whitney U test in research of professional training of primary school teachers. Metodicki Obzori, 6(11): 73-79. 
OUDE OPHUIS, P. A. M. and VAN TRIJP, H. C. M. 1995. Perceived quality: A market driven and consumer oriented approach. Food Quality and Preference, 6(3): 177-183.

QUINTAL, V., PHAU, I., SIMS, D. et al. 2016. Factors influencing generation Y's purchase intentions of prototypical versus me-too brands. Journal of Retailing and Consumer Services, 30(3): 175-183.

REA, L. M. and PARKER, R. A. 2014. Designing and conducting survey research: A comprehensive guide. $4^{\text {th }}$ edition. San Francisco, CA: Jossey-Bass.

RUGIMBANA, R. 2007. Generation Y, how cultural values can be used to predict their choice of electronic financial services. Journal of Financial Services Marketing, 11(4): 301-313.

STEM/MARK. 2015. Měření výsledků komunikačníkampaně chráněných označení ČESKÁ REPUBLIKA \& SLOVENSKO.In: Tiskovákonference 7.10.2015:Kvalitaz Evropy-chutěs príběhem. Available at: http://docplayer. cz/5237911-Tiskova-konference-7-10-2015-kvalita-z-evropy-chute-s-pribehem.html [Accessed: 2017, June 2].

STOKES, B. 2015. Who are Europe's Millennials? Pew Research Center. [Online]. Available at: http://www. pewresearch.org/fact-tank/2015/02/09/who-are-europes-millennials/_[Accessed: 2017, June 15].

SULLIVAN, P. and HEITMEYER, J. 2008. Looking at Gen Y shopping preferences and intentions, exploring the role of experience and apparel involvement. International Journal of Consumer Studies, 32(3): 285-295.

SZAKÁLY, Z., SOÓS, M., SZABÓ, S. et al. 2016. Role of labels referring to quality and country of origin in food consumers' decisions. Acta Alimentaria, 45(3): 323-330.

UNITED NATIONS. 2007. Safety and quality of fresh fruit and vegetables: A training manual for trainers. [Online]. $1^{\text {st }}$ edition. New York and Geneva: United Nations. Available at: http://unctad.org/en/docs/ditccom200616_ en.pdf [Accessed: 2017, May 17].

VAN RIJSWIJK, W. and FREWER, L. J. 2008. Consumer perceptions of food quality and safety and their relation to traceability. British Food Journal, 110(10): 1034-1046.

VELČOVSKÁ, Š. 2017. Perception of food products origin and its labelling by generation Y consumers. In: $8^{\text {th }}$ European Business Research Conference. ESCP Paris, 24-25 April. Berwick: World Business Institute, 1. [Online]. Available at: https://wbiworldconpro.com/uploads/paris-conference-2017/ marketing/1493121060.pdf. [Accessed: 2017, June 13].

VELČOVSKÁ, Š. and DEL CHIAPPA, G. 2015. The food quality labels: Awareness and willingness to pay in the context of the Czech Republic. Acta Universitatis Agriculturae et Silviculturae Mendelianae Brunensis, 63(2): 647-658.

VELČOVSKÁ, Š. and KLAPILOVÁ KRBOVÁ, P. 2016. Consumers' attitudes towards food quality labels in selected European Union countries. In: KOVÁŘOVÁ, E., MELECKÝ, L. and STANÍČKOVÁ, M. (Eds.). Proceedings of the 3rd International Conference on European Integration 2016. Ostrava, 19-20 May. Ostrava: VŠB Technical University of Ostrava, pp. 1068-1077.

VERBEKE, W. 2013. Food quality policies and consumer interests in the EU. In: KLOPČIČ, M., KUIPERS, A. and HOCQUETTE, J. F. (Eds.). Consumer attitudes to food quality products. EAAP publication No. 133. $1^{\text {st }}$ edition. Wageningen: Wageningen Academic Publishers, pp. 13-22.

VERBEKE, W., PIENIAK, Z., GUERRERO, L. et al. 2012. Consumers' awareness and attitudinal determinants of European Union quality label use on traditional foods. Bio-based and Applied Economics, 1(2): 213-229.

WJSCHROER. 2016. Generations X, Y, Z and the others. WJSchroer. [Online]. Available at: http:// socialmarketing.org/archives/generations-xy-z-and-the-others/_[Accessed: 2017, May 19].

Šárka Velčovská: sarka.velcovska@vsb.cz

Dominika Hadro: dominikahadro@gmail.com 